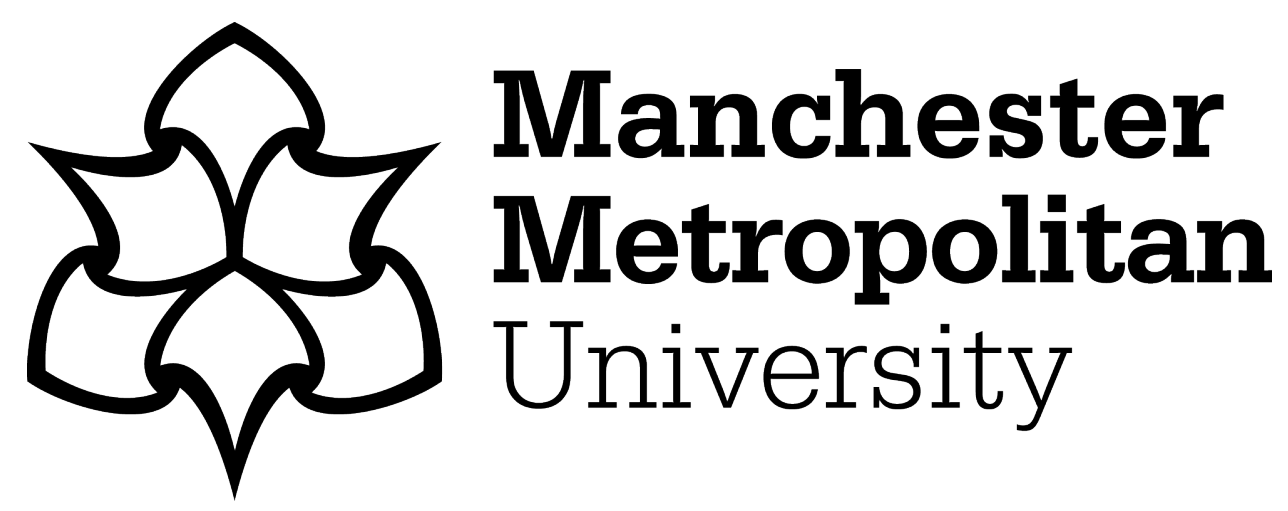

Pijetlovic, K (2017) EU sports law: a uniform algorithm for regulatory rules. International Sports Law Journal, 17 (1-2). pp. 86-100. ISSN 1567-7559

Downloaded from: https://e-space.mmu.ac.uk/622959/

Version: Accepted Version

Publisher: TMC Asser Press/Springer

DOI: https://doi.org/10.1007/s40318-017-0114-7

Please cite the published version 


\title{
EU sports law: A uniform algorithm for regulatory rules
}

\author{
Dr. Katarina Pijetlovic*
}

\begin{abstract}
In applying the EU economic provisions to the regulatory rules in sport, four different categories of "sporting exception" can be discerned in the jurisprudence of the Court. They include sporting rules that do not produce any economic effect, 'purely sporting' rules, inherent rules, and objectively justified rules. Based on the existing parameters of the EU sports law and policy, this article advances arguments in support of discarding the nuances in the Court's analytical approach to sporting exception. Ordinary EU law, coupled by the concept of specificity of sport that is now included in Article 165(1) TFEU, already contains the allencompassing, uniform analytical structure apt to accommodate all categories of regulatory rules in sports. In addition, the proposed uniform framework can be utilised to justify the challenged sporting rules in both internal market law and competition law, thus avoiding duplication of analysis. This is enabled by the high degree of convergence in their application to the rules of private regulatory bodies.
\end{abstract}

Keywords: Sport, regulatory rules, Meca-Medina, convergence, Article 165, burden of proof, private regulatory bodies, specificity of sport, inherent rules, sporting exception, Walrave, Bosman, Deliège, Lehtonen, Bernard

\section{Introduction}

The relationship between sport and EU law has steadily progressed over the past forty years. It moved from virtually apologetic ruling in Walrave (1974) that sport is subject to EU law "only in so far as it constitutes an economic activity" to a confident elucidation in Meca-Medina (2006) that any condition for engaging in sporting activity may offend against the EU law. It was the Court's decision in Bosman (1995) coinciding with the commercialisation of the industry that sparked policy discussions that focused on whether sport deserves a special treatment in the application of the TFEU economic provisions. In 2007 the Commission published White Paper on Sport accompanied by the Commission Staff Working Document, the most influential and comprehensive policy initiative thus far. It includes the Union acquis pertaining to the sports sector, sets out the general approach, and increases the transparency in relationship between sport and EU law.

Throughout this development of EU sports law and policy one of the most pertinent questions concerned the scope and content of sporting exception, i.e., the special treatment given to sports in the application of the EU economic provisions necessitated by certain specificities of the sector. This question received a heightened importance in the EU policy discussions after the Bosman judgement in 1995. Today, four types of sporting exceptions can be identified in the Court jurisprudence, each being subject to a different analytical framework depending on the

\footnotetext{
* Dr. Katarina Pijetlovic is a Senior Lecturer in EU law and sports law at Liverpool Hope University. She is the author of EU Sports Law and Breakaway Leagues in Football (Springer, 2015).
} 
nature of restriction in question. They include sporting rules that do not produce any economic effect, "purely sporting" rules, inherent rules, and objectively justified rules. Whereas constructing these structural nuances might have been useful initially to clarify the approach in the sporting sector, discarding them would make more sense today. Standard application of EU competition and internal market law to regulatory rules of private bodies, coupled by the (now constitutional) requirement to take into account the specificity of sport in the implementation of EU law, already contains the all-encompassing, uniform analytical framework apt to accommodate all categories of sporting rules. The core of this article rests with the premise that such uniform algorithm is preferable and should be utilised henceforth to the exclusion of any former distinctions between different categories of sporting exceptions. But before moving on to this discussion, the concept of specificity of sport and the application of the law as it stands today will be set out.

\section{Specificity of sport in EU law and policy}

Sports governing bodies are formally private entities occupying a monopolistic position in onefederation-per-sport pyramidal structures typical of most European sports. The self-governing model with a degree of political, legal, financial and pyramidal autonomy akin to the public entities, allows them to organise and regulate their respective sport in the way they see fit. The rules and regulations they adopt control the conduct within their disciplines, including athletes' professional lives, clubs' match calendars, and many aspect of clubs' business affairs and finances. This wide scope of regulatory latitude had by the sports governing bodies is not unfettered: in EU policy it is conditional upon their compliance with the EU law. ${ }^{1}$ In practice, however, lobbying strategies, out-of-court settlements and development of internal dispute settlement mechanisms have served sports governing bodies in alleviating the impact of EU law. ${ }^{2}$

The duty to comply with the EU law is matched by the corresponding duty of the Union to take into account the specificities of the sporting sector in the implementation of common policies. Some of the most distinctive of those specificities include mutual interdependence between clubs to produce a game integrated into wider championship race as the only marketable product; preserving competitive balance between clubs in order to increase the uncertainty of results; ${ }^{3}$ financial solidarity between competing adversaries and between professional and amateur levels of the game; transient nature of the industry, ${ }^{4}$ and; significant social, cultural and educational function performed by sport.

\footnotetext{
${ }^{1}$ Commission Staff Working Document, The EU and Sport: Background and Context, Accompanying Document to the White Paper on Sport, COM (2007) 391 final, para 4.1.

${ }^{2}$ Geeraert, Mrkonjic and Chappelet, "A rationalist perspective on the autonomy of international sport governing bodies: towards a pragmatic autonomy in the steering of sports", 7:4 International Journal of Sport Policy and Politics, (2015) 473-488, at 476.

${ }^{3}$ Simmons, "The demand for spectator sports" in Andreff and Szymanski (Eds), Handbook on the Economics of Sport (Edward Elgar 2009), 77-89, at 79.

${ }^{4}$ Individual sportsperson's careers are short and prone to many interruptions or abrupt endings due to injuries; sports broadcasting must take place as the event occurs; sports betting is a time-restricted game of chance and skill; commercial exploitation of, for example, certain sports merchandise, is limited to a short period in which the theme affixed to the item is popular; live attendance at the stadiums is a once-in-a-lifetime event, and so on. It is essential that the personal or commercial assets are used in timely fashion - otherwise the possibility of their exploitation is lost.
} 
In December 2009, the Lisbon Treaty amendments gave complementary competence to the Union in the area of sport, ${ }^{5}$ and introduced the concept of "specificity of sport" in Article 165(1) TFEU. This article states that "[t]he Union shall contribute to the promotion of European sporting issues, while taking account of the specific nature of sport, its structures based on voluntary activity and its social and educational function" [emphasis added]. The Commission Communication on Developing European Dimension in Sport interprets the specificity of sport in Article 165(1) TFEU as the concept encompassing "all the characteristics that make sport special $[\ldots]$ ". ${ }^{6}$ The first reference to Article 165(1) TFEU was made by the Grand Chamber of the Court in Bernard, ${ }^{7}$ even though the facts of the case pre-dated the entry into force of the Lisbon Treaty. Thus, the reference was largely symbolic as it merely reinforced already existing judicial possibilities and Article 165(1) TFEU added little further protection for contested sports rules beyond those already provided by the Court and the Commission - the two institutions have already been highly receptive of the "specific nature of sport" concept. ${ }^{8}$

Some examples of the objectives specific to the sporting community accepted as legitimate so far have been ensuring regularity of competitions, ${ }^{9}$ maintaining the competitive balance between clubs by preserving a certain degree of equality and uncertainty as to results ${ }^{10}$, encouraging the recruitment and training of young players, ${ }^{11}$ combating doping in order for competitive sport to be conducted fairly, objectively, and ethically, ${ }^{12}$ and ensuring integrity of competitions through prohibitions on multi-club ownership. ${ }^{13}$ However, the Commission Staff Working Document emphasises that each sport is different and has its specificities which deserve to be acknowledged under EU law. As such, the EU will not impose general rules applicable to all European sports. ${ }^{14}$

The specificity of sport is therefore the very feature of the industry that brought about "sporting exceptions" of various kinds in EU law. The content of these exceptions is determined on caseby-case basis. The Commission Staff Working Document on Sport and Free Movement (2011) states that "[e]xceptions from the EU's fundamental principles must be limited and based on specific circumstances". ${ }^{15}$

Next, we will look at the application of these principles and development of the different sporting exceptions in EU law.

\footnotetext{
${ }^{5}$ Articles 2(5) and 6 TFEU.

${ }^{6}$ Para 4.2 of the Communication, $\operatorname{COM}(2011) 12$ final, 18. 1. 2011.

${ }^{7}$ Case C-325/08 Olympique Lyonnais SASP v. Olivier Bernard and Newcastle United FC [2010] ECR I-2177. For detailed analysis of the judgement see Pijetlovic "Another Classic of EU Sports Jurisprudence: Legal Implications of Olympique Lyonnais SASP v. Olivier Bernard and Newcastle UFC (C-325/08)” 35 E.L.Rev. (2010), 858-869.

${ }^{8}$ Study on the Lisbon Treaty and European Union Sports Policy (2010). DG for Internal Policies: Policy Department B: Structural and Cohesion Policies Culture and Education, IP/B/CULT/IC/2010-028, p 11.

${ }^{9}$ Case C-176/96 Jyri Lehtonen and Castors Canada Dry Namur-Braine ASBL v. Fédération royale belge des sociétés de basket-ball ASBL (FRBSB) [2000] ECR I-2681, para 53.

${ }^{10}$ Case C-415/93 Union Royale Belge Sociétés de Football Association and others v. Bosman and others [1995] ECR I-4921, para 106.

${ }^{11}$ Ibid. and Case C-325/08 Bernard, para 39.

${ }^{12}$ Case C-519/04 David Meca-Medina and Igor Majcen v Commission [2006] ECR I-6991, para 43.

${ }^{13}$ Case IV/37.806 — ENIC/UEFA [2002] unpublished decision of 27 June 2002.

${ }^{14}$ Para 4.1 of the Commission Staff Working Document.

15 Commission Staff Working Document on Sport and Free Movement, accompanying document to the Communication from the Commission to the European Parliament, the Council, the European Economic and Social Committee, and the Committee of the Regions "Developing the European Dimension in Sport" COM(2011) 12 final, 18. 1.2011, p 7.
} 


\section{Four categories of sporting exception in the Court's jurisprudence}

When applying the internal market laws, the Court will first assess the existence of the restriction on the free movement. If a restriction is not found, the case ends in favour of the respondent. Where a restriction is identified, the Court goes on to evaluate the existence of legitimate justifications for the restrictions and the proportionality of the challenged measure. In EU free movement law, directly discriminatory measures can only benefit for the limited list of express derogations in the Treaty, whereas indirectly discriminatory and non-discriminatory restrictions have the additional recourse to the open list of objective justifications. Sport is an exception to this standard of application. By allowing the directly discriminatory ' $3+2$ ' rule in Bosman, ${ }^{16}$ discriminatory transfer windows in Lehtonen, ${ }^{17}$ and quotas on foreign players in Kolpak $^{18}$ and Simutenkov ${ }^{19}$ to be considered under the objective justification framework as opposed to the express derogation framework, the Court has effectively introduced the concept of "specificity of sport" to the traditional classification process. Sport is not the only sector in which the Court has taken such a detour for directly discriminatory measures, ${ }^{20}$ but it is the only sector where it has taken this approach consistently, thus making it a rule in the application of EU free movement law to sports, which can be attributed to the specificity of sport.

In competition law, Article 101(1) TFEU prohibits agreements between undertakings, decisions by associations of undertakings or concerted practices, which are considered capable of affecting trade between Member States and that have as their object (i.e., subjectively intend) or effect (i.e., objectively cause) $)^{21}$ the prevention, restriction, or distortion of competition within the internal market. Ancillary restraints, while prima facie restricting competition, will after examination fall outside the scope of Article 101(1) TFEU. As for the practices that do breach this provision, the fulfilment of the economic efficiency based criteria of Article 101(3) TFEU will be necessary for exemption. Article 102 TFEU prohibits the dominant undertakings to abuse their market position. An equivalent of ancillary restraints and economic efficiency criteria of Article 101(3) TFEU apply under Article 102 TFEU to exempt otherwise illegal behaviour.

Parrish and Miettinen described the sporting exception in EU law as "both the removal of rules from the scope of these Treaty articles and the sensitive application of EU law to the sports sector". ${ }^{22}$ Four categories of rules that qualify for the sporting exception in this broad meaning

\footnotetext{
${ }^{16}$ Case C-415/93 Bosman.

${ }^{17}$ Case 176/96 Lehtonen.

${ }^{18}$ Case C-438/00 Deutscher Handballbund v. Kolpak [2003] ECR I-4135.

${ }^{19}$ Case C-265/03 Igor Simutenkov v. Ministerio de Educación y Cultura, Real Federación Española de Fútbol [2005] ECR I-2579.

${ }^{20}$ See, for e.g., Case C-67/97 Bluhme [1998] ECR I-6717 (biodiversity), Case C-2/90 Commission v. Belgium (Walloon Waste) [1992] ECR I-4431 (environmental protection), Case C-19/92 Kraus [1993] ECR I-1663 (protection of public against misleading use of academic titles).

${ }^{21}$ For the concept of "effects on trade", see Case C-56/65 Societe Technique Miniere v. Maschinenbau Ulm (STM) [1966] ECR 235, para 7; Case 56/64 Consten and Grundig [1966] ECR 299, para 27. See also European Commission, Guidelines on the effects on trade concept contained in Articles 81 and 82 of the Treaty [2004] OJ C $101 / 81$.

${ }^{22}$ Parrish and Miettinen, The Sporting Exception in European Union Law (T.M.C. Asser Press 2008), p 73.
} 
can be identified in the examination of the Court's jurisprudence. ${ }^{23}$ The first three are represented by the sporting rules that are not considered to be in breach of the Treaty, whereas the rules that qualify as category IV exception are restrictions that can nevertheless be justified.

\subsection{Category I: Sporting rules that do not produce any economic effect}

Category I is represented by the sporting rules that do not produce any economic effect. In paragraph 4 of Walrave the Court addressed and confirmed the applicability of the Treaty in the area of sport and held that "the practice of sport is subject to Community law only in so far as it constitutes economic activity [...]". ${ }^{24}$ Accordingly, the lack of economic effect is the sole fact that is per se sufficient to take the rule outside of the scope of the Treaty and outside of Union competence. Both the sporting rule and its effects must be non-economic to merit from this relatively limited exception in terms of its practical scope. Apart from the rules of the game (lex ludica $)^{25}$ that are unlikely to be challenged before the courts, and sport as purely amateur pursuit, it is hard to imagine a rule completely devoid of any economic effect.

In Donà, the Court specifically mentioned only professional and semi-professional players as subjects of protection under freedom of movement provisions. ${ }^{26}$ This implied that the rules applicable to amateur, non-economic activities do not fall under the protection afforded by the Treaty. At the same time, the "amateur athlete" designation by the sporting federation does not automatically exclude those covered by it from the scope of the Treaty. A functional case-bycase rather than strictly formalistic approach will be employed in examining the existence of economic activity that falls under the scope of the Treaty. Thus, in Deliège the Court first said that "the mere fact that a sports association or federation unilaterally classifies its members as amateurs does not in itself mean that those member do not engage in economic activities." ${ }^{27}$ It went on to set a broad criteria to determine whether an activity engaged in by the amateur athlete constitutes economic activity within the meaning of paragraph 4 of Walrave. Grants and sponsorship agreements received by the athlete, as well as the fact that participation of formally amateur athletes in international competitions is a source of profit for competition organisers were considered relevant factors in the context.

In that sense, there is nothing special in application of EU law to sporting industry in respect to this category of sporting exception: any activity which does not constitute economic activity will fall outside the scope of the Treaty's economic provisions. For example, in non-sporting cases Levin and Steymann ${ }^{28}$ the Court required that the work performed must be genuine and effective and not such as to be regarded as purely marginal and ancillary, thus clearly indicating the need for the requisite minimum economic effect. As such, Category I is not exactly a "sporting" exception, but an exception with general pertinence. It is also not exactly an

\footnotetext{
${ }^{23}$ Ibid. pp 73-101.

${ }^{24}$ Case 36/74Walrave and Koch v. Union Cycliste Internationale and others [1974] ECR 1405.

25 As defined by Foster, "Lex sportiva and lex ludica: The CAS's jurisprudence" in Blackshaw, Siekmann, and Soek (Eds.), The CAS 1984-2004 (T.M.C. Asser Press 2006), p 421. The rules of the game are, for e.g., offside in football, the dimensions of a tennis court, the number of fielded players, etc.

${ }^{26}$ Case 13/76 Gaetano Donà v. Mario Mantero [1976] ECR 1333, para 19.

${ }^{27}$ Joined Cases C-51/96 and C-191/97 Christelle Deliège v. Ligue francophone de judo et disciplines associées ASBL, Ligue belge de judo ASBL, Union européenne de judo and François Pacquée [2000] ECR I-2549, para 46.

${ }^{28}$ Case 53/81 D.M. Levin v. Staatssecretaris van Jusitie [1982] ECR 1035, para 17 and Case 196/87 Udo Steymann v. Staatssecretaris van Jusitie [1988] ECR 6159, para 13.
} 
"exception" as the rules not covered by the Treaty do not require any exception. All other sporting rules and practices will be scrutinised for their compatibility with the Treaty.

Finally, it is important to note that this exception sets a generally applicable constitutional limitation on the conferred powers of EU institutions, and as such applies to challenges to regulatory rules under competition provisions as well.

\subsection{Category II: “Purely sporting” rules}

In paragraph 8 of Walrave the Court made an exception for directly discriminatory sporting rule on selection of athletes for national representative teams. Specifically, in regard to nationality discrimination as prohibited under Articles 18, 45 and 56 TFEU, the Court said that such prohibition "does not affect the composition of sport teams, in particular national teams, the formation of which is a question of purely sporting interest and as such has nothing to do with economic activity." In paragraph 9 it added that "this restriction on the scope of the provisions in question must however remain limited to its proper objective." Accordingly, the Treaty would not apply to economic sporting activities so long as the motive for the proportionate rules was non-economic, in other words, "purely sporting".

In Dona ${ }^{29}$ the case that also concerned the composition of sport teams (albeit not national teams) the Court modified and restricted the rule in paragraph 8 of Walrave. The exception to prohibition on direct discrimination for composition of national representative teams was reformulated and substituted with exclusion of "foreign players from participation in certain matches for the reasons which are not of an economic nature, which relate to the particular nature and context of such matches and are thus of sporting interest only". ${ }^{30}$ Matches between national teams from different countries were mentioned as an example of the kind of exclusion of players that will fall under Category II of sporting exception.

Purely sporting rules are therefore the rules that: 1) produce required economic effect, 2) are based on non-economic, purely sporting motives, 3) relate to the particular nature and context of certain matches, and 4) are proportionate.

Although the Court has created and used this exception in the application of free movement provisions, it may well be applicable (solely or simultaneously) in competition law provided the case has required economic effect needed to trigger the application of Articles 101 and 102 TFEU. While there is a high level of convergence between competition and internal market articles in their application to regulatory rules, they also possess some very individual features which prevent the full convergence in their application to such rules. For example, purely internal situations are outside of the scope of internal market rules and therefore outside of Union competence, ${ }^{31}$ but the competition rules may apply even if the situation is wholly internal, as long as there is the required effect on competition. Similarly, the restriction on competition which does not produce an appreciable effect on the trade between Member States is outside of the EU competence in respect to competition provisions, but it may fall to be examined by the EU institutions under the free movement articles. Certain other elements such as undertaking, agreement or decision, dominance, service, worker, etc., further prevent the full

\footnotetext{
${ }^{29}$ Case $13 / 76$ Donà.

${ }^{30}$ Ibid. para 14.

${ }^{31}$ See, for example, Case 175/78 Regina v. Saunders [1979] ECR 1129 and Cases C-225-227/95 Kapasakalis, Skiathis and Kougiagakas v. Greece [1998] ECR I-4329.
} 
convergence between the two sets of provisions. All these individual features and conditions can be referred to as "required economic effects".

The application of the "purely sporting" rule exception is triggered by the presumption of the restriction of the specific Treaty provision. Such application also implies that the required economic effect was found to exist. The rest of the conditions for Category II exception (i.e., purely sporting motive, participation in certain matches, and proportionality) are exactly the same for internal market and competition law, and concerning those conditions, there exists full convergence. Once the rule satisfies the required economic effect test for application of both sets of provisions, it reaches the common ground for assessment of the applicability of conditions for exemption.

This conclusion is valid in all but one situation: cases that involve conclusive presumptions under Article 101(1) TFEU. The language in paragraph 31 of Meca-Medina implies that the rule that already satisfied the requirements for exception under the free movement provisions cannot be taken to automatically satisfy those requirements under competition provisions. This has been interpreted by many authors as the Court's rejection of convergence theory. However, this is not the case. Apart from the required economic effect that was discussed in the preceding paragraphs, all that the Court was suggesting is that the internal market law does not have the equivalent of the hard-core restrictions in Article 101(1). Under Article 101(1), if a rule constitutes a per se or hard-core restriction by object, it is not open to the parties to argue that it in fact does not amount to a restriction and the presumption of a breach of that provision is conclusive, as opposed to rebuttable. In that case, a rule that has satisfied all the requirements for the category II exception under the free movement provisions cannot benefit from the attempt at that exception under Article 101(1) to which it would otherwise be entitled but for the hard-core restrictions and conclusive presumptions of the breach. A party may rely on Article 101(3) but not on any of the judicially-developed exceptions available on the level of the restriction under Article 101(1). Conversely, if there is no conclusive presumption under the competition provisions, and the rule has already been regarded under internal market articles as "purely sporting", that result is transplantable to competition law, with no further analysis being required. The paragraph 31 in Meca-Medina should be read in this light. Once there is a rebuttable (non-conclusive) presumption under competition articles, and the "required economic effect" is established under both sets of provisions, the three remaining conditions for exception are the same. ${ }^{32}$

Finally, it must be mentioned that the exception for purely sporting rules does not present an unfamiliar legal construction in the EU law. Before Meca-Medina, it could have been considered as a judicially fashioned sporting equivalent to Article 45(4) TFEU exception for directly discriminatory measures regarding employment in the public service, due to its application being confined only to the context involving direct discrimination for national representative teams.

\subsection{Category III: Inherent rules}

The concept of inherent rules originated in internal market case Deliège in which the Court was asked to determine the compatibility with Article 56 (and 101 and 102) TFEU of selection rules

\footnotetext{
${ }^{32}$ For detailed analysis of convergence see Pijetlovic, EU Sports Law and Breakaway Leagues in Football, (Springer, 2015), pp 215-235.
} 
of governing body for judo in Belgium limiting the number of participants in the high-level international competitions (Olympic Games) that do not involve national teams competing against each other. The question forwarded to the Court was whether it was contrary to those articles to "require professional or semi-professional athletes, or persons aspiring to professional or semi-professional activity, to be authorised by their federation in order to be able to compete in international competition which does not involve national teams competing against each other". 33

The Court first reiterated and confirmed the scope of the sporting exception as set out in Walrave (paragraph 4) Donà (paragraphs 14 and 15) and Bosman (paragraphs 76 and 127), but dismissed the applicability of both the Category I and II sporting exception. It recognised that unlike in Bosman the rules challenged in Deliège "do not determine the conditions governing access to the labour market by professional sportsmen and do not contain nationality clauses limiting the number of nationals of other Member States who may participate in a competition". ${ }^{34}$ Selection rules at issue in the main proceedings were thus considered as nondiscriminatory rules affecting the exercise of economic activity, rather than as discriminatory market access rules. ${ }^{35}$ Only then it proceeded to specify that challenged rules could not in themselves constitute an obstacle on the freedom to provide services under Article 56 TFEU because limiting the number of participants "is inherent in the conduct of an international highlevel sports event, which necessarily involves certain selection rules or criteria being adopted". ${ }^{36}$ The sports organisations also must be able to demonstrate that selection rules are based on objective criteria unconnected with the personal circumstances of the athletes. ${ }^{37}$

Although the Court did not explicitly mention that the inherent rules should be proportionate, such requirement follows from paragraph 65 of the judgment that reads

[...]the adoption, for the purposes of an international sports tournament, of one system for selecting participants rather than another must be based on a large number of considerations unconnected with the personal situation of any athlete, such as the nature, the organisation and the financing of the sport concerned.

Accordingly, the discriminatory rule would be considered disproportionate and the inherency test failed. In Deliège, the adoption of one system over another is left to sporting bodies and organisers, ${ }^{38}$ as long as the selection is made on the basis of objective factors unconnected with the athletes' personal situation. The proportionality of such a system is not questioned by the Court as it is deemed proportionate by default. Hence, the reason that the Court did not specifically mention the proportionality requirement is because it is built into the concept of

\footnotetext{
${ }^{33}$ Joined Cases C-51/96 and C-191/97 Deliège, para 22.

${ }^{34}$ Ibid. para 61.

${ }^{35}$ Under the "Säger formula" this would have been enough to find a breach. Para 12 of Case C-76/90 Säger [1991] ECR I-4221 provides that Article 56 required: "not only the elimination of all discrimination against a person providing services on the ground of his nationality but also the abolition of any restriction, even if it applies without distinction to national providers of services and to those of other Member States, when it is liable to prohibit or otherwise impede the activities of provider of services established in another Member State where he lawfully provides similar services". See on this point Miettinen and Parrish "Inherent Rules in EC Sports Law", presented at the Conference on Law and Popular Culture, Onati, Spain (June 2008).

${ }^{36}$ Ibid. para. 64, (emphasis added).

${ }^{37}$ Ibid. para 65.

${ }^{38}$ Ibid. paras 67 and 68.
} 
inherency under free movement law. Only non-discriminatory (i.e. proportionate) rules that do not relate to market access can satisfy the inherency test under free movement provisions. ${ }^{39}$

The inherency test for regulatory rules in sport under competition law articles is not sensitive to the difference between the discriminatory and non-discriminatory, and between market access and exercise of economic activity rules. Its scope is therefore broader and more flexible. The origins of the inherency test can be found in Wouters, a case involving regulatory rules of the Bar of the Netherlands, where the Court introduced an exception, characterised by Whish as a "regulatory ancillarity". ${ }^{40}$ The exception essentially involves the balancing of the Union's competition law objectives against the non-economic public interests that may or may not be a part of the Union's objectives in other areas. The Wouters test was confirmed in Meca-Medina, which remains the only case involving regulatory rules in sport decided under Articles 101 and 102 TFEU to date. ${ }^{41}$ It concerned two professional swimmers who were suspended due to the breach of sport's anti-doping rules adopted by the International Olympic Committee. The applicants contested the rules alleging that they were in breach of the freedom to provide services and the competition provisions of the Treaty. The Court emphasised the need for contextual approach when assessing the existence of restriction under Article 101(1) TFEU:

Not every agreement between undertakings or every decision of an association of undertakings which restricts the freedom of action of the parties or of one of them necessarily falls within the prohibition laid down in Article [101(1) TFEU]. For the purposes of application of that provision to a particular case, account must first of all be taken of the overall context in which the decision of the association of undertakings was taken or produces its effects and, more specifically, of its objectives. It has then to be considered whether the consequential effects restrictive of competition are inherent in the pursuit of those objectives (Wouters and Others, paragraph 97) and are proportionate to them. ${ }^{42}$

Accordingly, certain types of agreements or decisions that restrict the commercial behaviour of undertakings do not violate the prohibition in Article 101(1) TFEU, if, because of their context and objectives, the restrictions in those agreements or decisions are inherent to, and proportionate for, the realisation of non-competition objectives. From the scarce case law on regulatory ancillarity, it appears that the exception is applicable only in cases of regulatory restrictions imposed by collective private bodies in public interests, whether at national, European or global level. So far, the Court has applied it only to rules having a public law character deemed necessary for the proper organisation and (ethical) conduct of a certain profession. The fact that the doping rule was intended to safeguard the objective of fair play and ethics in sports did not remove it from the scope of competition rules; the economic effects that it produced had to be considered in the light of the Wouters inherency test and the requirement of proportionality. The rule was found to restrict athletes' freedom of action, but as the general objective was to provide a level playing field and preserve integrity of sporting competition and the sanctions were necessary to ensure compliance with the doping ban, the

\footnotetext{
${ }^{39}$ Miettinen and Parrish, op. cit. supra note $\mathrm{xxx}$

${ }^{40}$ Whish, Competition Law, $6^{\text {th }}$ edn. (OUP, 2009), p xxx.

${ }^{41}$ Case C-519/04 Meca-Medina. Before this case the Court has had a number of opportunities to clarify the relation between competition law and sports (notably in C-415/93 Bosman) but it has avoided this problem by deciding the cases on the basis of internal market rules. In the absence of Union legislative competence, it was only the Commission decisional practice that shed some light on the competition law issues in sports.

${ }^{42}$ C-519/04 Meca-Medina, para 42.
} 
restrictions were deemed inherent in the rule. ${ }^{43}$ The Court also found that athletes had not demonstrated that the rule was disproportionate. ${ }^{44}$

The rule or practice which is found to satisfy the cumulative criteria of the test is considered compatible with Articles 101 and 102 TFEU. One the other hand, should the rule or practice fail to meet any of the criteria, and it has a negative effect on trade between Member States, it will breach Article 101(1) TFEU and will constitute an abuse contrary to Article 102, which can be made valid only by satisfying the conditions for exemption common to both articles (i.e., Article 101(3) TFEU and the efficiency defence conditions). Here, it must be acknowledged that it is highly unlikely that a rule of a sporting organisation pursuing a non-competition goal that cannot be translated into economic efficiencies, or a rule that has failed the Meca-Medina test on the point of proportionality, would satisfy the requisite economic conditions. ${ }^{45}$ That presents raison d'être of the Meca-Medina test, for without it, the broad scope of Article 101(1) TFEU would likely render virtually any organisational rule of sport that restricts the freedom of action and relies on the non-competition justification incompatible with the entire Article 101 TFEU.

The Commission in its Communication did not differentiate between competition and internal market law when it explained that in order to assess the compatibility of sporting rules with any EU law, it considers 1) the legitimacy of the objectives pursued by the rules; 2) whether any restrictive effects of those rules are inherent in the pursuit of the objectives, and; 3) whether they are proportionate to them. ${ }^{46}$ So these are the common requirements under the inherency test for both sets of provisions, whether or not explicitly stated. According to the Commission Staff Working Document ${ }^{47}$, the rules that have been, or are likely to be, considered inherent under competition law provisions are: non-discriminatory transfer windows, ${ }^{48}$ nondiscriminatory criteria for selection of athletes for competitions, ${ }^{49}$ proportionate sanctions for breach of anti-doping rules, ${ }^{50}$ proportionate home-and-away rules, ${ }^{51}$ and proportionate rules preventing multiple ownership of clubs. ${ }^{52}$

\footnotetext{
${ }^{43}$ Ibid. paras 43-44.

44 Ibid. para 55.

${ }^{45}$ The Commission in Commission Staff Working Document, Annex I, para 2.1.6, says that "[s]uch a justification is most likely to apply where a rule is not inherent in the organisation or proper conduct of sport so as to justify the application of Wouters but where the beneficial effects of a rule outweigh its restrictive effects."

${ }^{46}$ Communication from the Commission to the European Parliament, the Council, the European Economic and Social Committee, and the Committee of the Regions "Developing the European Dimension in Sport" COM(2011) 12 final, 18. 1. 2011, para 4.2.

${ }^{47}$ Commission Staff Working Document, The EU and Sport: Background and Context, Accompanying Document to the White Paper on Sport, COM (2007) 391 final, Annex I, para 2.4.

${ }^{48}$ Such as in Case C-176/96 Lehtonen.

${ }^{49}$ Such as in Joined Cases C-51/96 and C-191/97 Deliège.

${ }^{50}$ Such as in Case C-519/04 Meca-Medina.

${ }^{51}$ Such as in Case COMP/E3/36.85 — Lille/UEFA ("the Mouscron case") unpublished Commission Decision of 3 December 1999. Commission Press Release IP/99/965 "Limits to Application of Treaty Competition Rules to Sport: Commission Gives Clear Signal” 9 December 1999. See also XXIXth Report on Competition Policy 1999, pp 166-167.

${ }_{52}$ Several years before Meca-Medina, in ENIC the Commission directly applied Wouters inherency test in its positive assessment of the UEFA rule on multi-club ownership. See Commission Decision in Case COMP/37.806 — ENIC/UEFA. See also Commission Press Release IP/02/942 "Commission Closes Investigation into UEFA Rule on Multiple Ownership of Football Clubs”, Brussels 27 June 2002.
} 


\subsection{Category IV: Objectively justified sporting rules}

Category IV comprises the only type of regulatory sporting rules that initially constitute restrictions, both in fact and in law. They fit into generally applicable objective justification framework set out in Gebhard and Kraus. ${ }^{53}$ Accordingly, those restrictive rules that pursued a legitimate aim compatible with the Treaty and were justified by pressing reasons of public interest, and are compatible with the principle of proportionality do not breach the free movement provisions. ${ }^{54}$ Unlike in cases that concern other industries, in sport cases the Court utilises the Gebhard/Kraus-style framework for both directly and indirectly discriminatory rules. ${ }^{55}$ As Parrish and Miettinen put it, the test for objectively justified rules in sport involves a sensitive application of the law, ${ }^{56}$ in other words, the recognition of the specificities of the sports industry in the enforcement of the law. Examples of this exercise can be seen in Bosman, Lehtonen, and Bernard.

Bosman involved a directly discriminatory " $3+2$ " rule passed by Union of European Football Associations (UEFA) that placed quota on clubs in fielding foreign players, and nondiscriminatory transfer fee rules which restricted the professional activities of football players. With regard to the latter, in view of the considerable social importance of football in the EU, the Court acknowledged encouraging the recruitment and training of young players and maintaining the competitive balance between clubs as legitimate objectives. ${ }^{57}$ The transfer fees were found unsuitable for the attainment of the said objectives and also failed the proportionality test (but only regarding the expired contracts). ${ }^{58}$ The Court also brushed aside the attempts to justify quotas on the basis of their alleged necessity to maintain the traditional link between each club and their country, to create a sufficient pool of top national players to be fielded in national representative team, and to maintain competitive balance between clubs. ${ }^{59}$ The fact that the quota rule was drawn up in collaboration with the Commission did not shield it from judicial scrutiny or provide any guarantees as to its compatibility with the Treaty. Thus, it was abolished by the Court. In the light of the answers under Article 45 TFEU, it was unnecessary to address the questions on interpretation of Articles 101 and 102 TFEU that were also referred to it for a preliminary ruling. ${ }^{60}$ However, AG Lenz in Bosman entertained the arguments of the respondent that referred to the "rule of reason", a concept applied in the US under Article 1 of the Sherman Act. While he acknowledged that Europe does not have the "rule of reason" doctrine and instead uses Article 101(3) TFEU as a platform for exemption analysis, he nevertheless found a functional equivalent that existed at the time in the form of the $D L G$ case $^{61}$ on commercial ancillarity, a precursor to Wouters case that contained the same

\footnotetext{
${ }^{53}$ Case C-55/94 Gebhard [1995] ECR I-4165; Case C-19/92 Kraus [1993] ECR I-1663.

${ }^{54}$ Ibid. paras 37 and 32, respectively.

${ }^{55}$ Discriminatory measures normally can only benefit from the exhaustive list of Treaty-based exceptions such as public policy, public health, and public security, but not from an open list of justifications available to nondiscriminatory measures. Sport is an exception to this rule.

${ }^{56}$ Parrish and Miettinen, op. cit. supra note xxx, $\mathrm{p} 73$.

${ }^{57}$ Bosman, para 106.

${ }^{58}$ Ibid. paras 109-113.

${ }^{59}$ Ibid. paras 121-137.

${ }^{60}$ Ibid. para 138.

${ }^{61}$ Case C-250/92 Gøttrup-Klim e.a. Grovvareforeninger v Dansk Landbrugs Grovvareselskab AmbA (DLG) [1994] ECR I-5641.
} 
basic approach to assessment of legality of restrictions as the core competition test applied to sporting rules today. ${ }^{6}$

In Lehtonen, the transfer of a basketball player did not take place within the specified one month period, i.e. within the so-called "transfer window" passed by the International Basketball Federation. A player that was not employed within the specified period could not play for his team in competitions for that season. Citing Bosman, the Court reiterated in paragraph 50 of Lehtonen that being fielded is the "essential purpose of a professional player's activity" and the rules prohibiting fielding restrict the chances of being employed. Because they affected labour market access as opposed to the exercise of economic activity, transfer windows were not inherent rules, but instead restrictions to free movement that fell to be examined under the objective justification framework. ${ }^{63}$ The Court found them justified on non-economic grounds, namely the need for proper organisation of the game because mid-season transfers could substantially alter the sporting strength and, therefore, the competition between teams in the course of a championship. ${ }^{64}$ Nevertheless, transfer windows in this particular case were found to be disproportionate and in breach of Article 45 TFEU because they were opened substantially longer for the players from outside the EU, which proved that the game can be organised properly with longer transfer windows. ${ }^{65}$ The questions on the interpretation of competition provisions were considered inadmissible due to the insufficient factual information provided by the referring national court. Advocate General Alber in Lehtonen considered the rule prima facie restrictive, but adopted the $D L G$ reasoning that necessary and proportionate rules may be saved from being labelled as restrictions. ${ }^{66}$

In Bernard, ${ }^{67}$ a young footballer was required to pay damages for the loss suffered by the club that trained him. This was a method of compensation for signing his first professional contract with another club and, consequently, breaching his contractual obligations. The Court found that the compensation scheme in Bernard, while constituting neither a prohibition on signing a contract with a club in another Member State nor discrimination on the basis of nationality, nevertheless discourages the player from exercising his right of free movement by making that exercise less attractive. ${ }^{68}$ Much like in Bosman, the Court took into account the considerable social importance of sporting activities, in particular football, in the EU, and accepted the objective of encouraging recruitment and training of young players as legitimate. ${ }^{69}$ The social importance of sport played a crucial role in legitimating this objective, a feature not found in any other employment sector.

The standard of application of the proportionality principle in the objective justification framework was set out by the Court in paragraph 40 of the Bernard case. Accordingly, when testing the sporting rules for their proportionality with the purported public interest objectives,

\footnotetext{
${ }^{62}$ AG Lenz Opinion in C-415/93 Bosman, paras 269-270.

${ }^{63}$ Case 176/96 Lehtonen, paras 47-50.

${ }^{64}$ Ibid. paras 51-55.

${ }^{65}$ Ibid. paras 56-58. It was nevertheless left for the national court to ascertain whether there were any objective reasons that could justify this difference in the transfer windows (see para 59).

${ }^{66}$ Opinion of Advocate General Alber in Case C-176/96 Lehtonen delivered on 22 June 1999, paras 107-108.

${ }^{67}$ Case C-325/08 Bernard.

68 Ibid. paras 23-37.

${ }^{69}$ Ibid. para 39.
} 
account must be taken of the specific characteristics of sport and of its social and educational function. This obligation on EU institutions is mentioned in identical terms in Article 165(1) TFEU and is therefore a constitutionally based requirement. As such, it can be said that the same standard applies in the interpretation and application of EU competition law to sport. In Murphy Advocate General Kokott was of the opinion that Articles 6(e) and 165 TFEU "require account to be taken of the specific nature of sport and its structures based on voluntary activity" 70 which has been interpreted to "imply horizontal reach of Article 165 into other Treaty competences." $" 71$

These cases illustrate that the specificity of sport is properly taken into consideration in the application and enforcement of EU internal market law in the objective justification framework. The phrasing of the requirement that "account must be taken of the specific characteristics of sport" is broad enough to capture any and all of the sports idiosyncrasies.

Although it is not as explicitly enunciated, same sporting considerations will be taken into account when applying EU competition law to regulatory rules in sport. This is due to not just the constitutionally based requirement in Article 165(1) TFEU but also because it would not be compatible with established case-law to utilise a different approach. The substance of the Category IV sporting exception for objectively justified rules is contained in the Meca-Medina test. Under competition provisions that test is the same as objective justification test under internal market, because it is not sensitive to nuances between the rules affecting market access (that are not capable of constituting inherent rules under internal market provisions and are assessed under objective justification framework) and the non-discriminatory rules affecting exercise of economic activities (that are capable of constituting inherent rules under internal market provisions). In other words, sporting rules that are subject to either inherent or objectively justified rule test under internal market, are subject to a single Meca-Medina test under competition law. This point will be further emphasised below.

\section{The uniform analytical framework}

The discussion so far lead us to the main premise of this article, which argues for the establishment of a uniform analytical framework under EU law for all categories of sporting rules. It is submitted that it ought to replace the distinct structural approaches to different categories of sporting rules that were created in the Court's jurisprudence without the need to introduce any new elements in the general EU sports law. Adequate evaluation of those rules can be carried out under the objective justification framework in internal market which corresponds to Meca-Medina test under competition law. Such uniform structural approach is not just preferable for the reasons of simplicity and legal certainty, but is also called for by the high level of convergence between treatment of regulatory rules under competition and internal market. This is further coupled by arguments that both purely sporting and inherent rules can perfectly fit in objective justification framework that already takes into account all the sporting specificities. In other words, sport has carved its place in the general EU law.

\footnotetext{
${ }^{70}$ Opinion of AG Kokott in Joined Cases C-403/08 and C-429/08 FAPL and others v. QC Leisure and others; and Karen Murphy v Media Protection Services Ltd [2011] ERC I-9083, para 207.

${ }^{71}$ Parrish, "Lex Sportiva and the European Union Sports Law", 37 E.L.Rev. (2012), 716-733, at 732. However, there is no need to take Article 165 TFEU into consideration in any of the EU legislative procedures, as it is not a horizontal provision.
} 
It remains to be acknowledged that Category I, represented by sporting rules that do not produce any economic effect, is not of importance for the purposes of the discussion to follow. As a matter of principle of subsidiarity those rules are outside of the EU competence. The remaining three categories that do produce economic effect can be subsumed under Category IV sporting exception. This involves treating purely sporting rules and inherent rules under objective justification framework.

\subsection{Purely sporting rules as objectively justified rules}

There are several reasons why the notion of purely sporting rule that forms category II sporting exception from Walrave and Dona ${ }^{72}$ should be discarded, and any challenges to the rules of sporting bodies previously belonging to this category should be dealt with under the single internal market law objective justification framework/competition law Meca-Medina framework.

First, even though the notion of purely sporting rule has always been plagued with uncertainties as regards its scope and precise meaning, the scope of exception is "extremely narrow". ${ }^{73}$ This view is in accordance with the Opinion of Advocate General Warner in Walrave that the exception is limited to representative nature of national teams only. The language of the Court would, however, indicate a wider approach as it extends the exception from the principle of non-discrimination on the basis of nationality to "sports teams", but "in particular national teams". Regardless of such language, there are no examples of practical application of the rule in sports outside of the nationality requirement for composition of national representative teams, and the Court has never used it in any other context. Advocate General was conscious of the difficulty in determining whether a pacer and a stayer in Walrave could constitute a "national team" and advised the Court to avoid giving the national court guidance on that concept. In following his advice the Court created "uncertainties that have plagued the application of EU rules to sport ever since." 74 On the basis of this it can be assumed that the purely sporting rule exception is confined to a single sporting rule.

Second, the developments in EU sport jurisprudence since Walrave and Donà rulings, in terms of treatment of specificities of sport, as well as the introduction of Article 165(1) TFEU by the Treaty of Lisbon, renders the purely sporting rule exception entirely superfluous. Paragraph 8 of Walrave can be taken as objective justification because the process of arriving at the conclusion that a certain sporting rule is "purely sporting", within the meaning of Walrave and Donà judgements, entails the process that is "not unlike that of objective justification". ${ }^{75}$ Sports federations have to demonstrate that the rule producing economic effect is objectively justified by reference to its purely sporting nature and an absence of economic motives (regardless of its economic effects), and that it is "limited to its proper objectives", which is a reference to proportionality requirement. This will render any rule that can pass the purely sporting rule test compatible with the general EU law under objective justification framework. Justifications which certainly belong to the notion of specificity of the sport can be put forth, and provided

\footnotetext{
${ }^{72}$ Case 36/74 Walrave and Case 13/76 Donà.

${ }^{73}$ Parrish and Miettinen, op. cit. supra note $\mathrm{xxx}, \mathrm{p}$

${ }^{74}$ Ibid. p 75.

${ }^{75}$ Ibid. p xxx
} 
the rule is not disproportionate, it will pass the objective justification test. It must be reiterated that this conclusion is enabled by the unorthodox approach in the Court's sports law jurisprudence that allows a non-exhaustive list of judicially developed justifications to be utilised for directly discriminatory rules. Standard approach is to allow only the Treaty-based derogations (public security, public policy and public health) for directly discriminatory measures.

Third, although functional parallels may be drawn between purely sporting rule and Articles 45(4) and 51 TFEU that safeguard certain types of directly discriminatory rules by providing exceptions for employment in public service and exercise of official authority, respectively, paragraph 27 of Meca-Medina has put an end to any such comparison. It states that "the mere fact that a rule is purely sporting in nature does not have the effect of removing from the scope of the Treaty the person engaging in the activity governed by that rule or the body which has laid it down". In Weatherill's interpretation of this paragraph, the so-called rule of "purely sporting interest", originating in Walrave, has been eliminated as a basis for immunising sports rules which have an economic effect from review under EU law. ${ }^{76} \mathrm{He}$ then correctly pointed out that the vast majority of rules adopted by sporting federations produce such economic effect, but that this does not mean that they will be held incompatible with the EU law after assessment. In the view advanced by this article, the outcome of such assessment hinges upon satisfying the objective justification/Meca-Medina test.

By holding that exclusion of foreign players from "national teams", and later in Donà from "participation in certain matches", falls outwith the scope of the Treaty, the Court attempted to remove purely sporting rules out of the general EU law and appeared to have created a novel exemption. But there exist clear advantages in terms of simplicity and legal certainty in discarding the category II exception and relocating the purely sporting rules under the wellestablished analytical structure, and this is now supported by paragraph 27 of Meca-Medina.

Finally, in the Commission Staff Working Document, Annex I, "purely sporting" rules are also contained in the notion of inherent rules under competition provisions, which apply to a much broader category of organisational sporting rules. ${ }^{77}$ Specifically, the Commission considered that the "purely sporting" rule from Walrave would likely meet the Meca-Medina test. ${ }^{78}$ This point could have been more strongly stated to reflect the idea that a rule that survives the purely sporting rules test will necessarily also pass the Meca-Medina test. Regulatory rules in sport that can be justified on the basis of "purely sporting" interests (or motives), within the meaning of Walrave and Donà judgments, automatically furnish the required public policy objectives under the Meca-Medina test, whereas the considerations that apply in evaluation of proportionality of such rules would remain the same under both analytical structures. This line of logic also applies to "purely sporting" rule as being capable of automatically satisfying the objective justification test in the free movement area. The concept of specificity of sport that is recognized by the jurisprudence of the Court and set out in Article 165(1) TFEU is a guarantee that nationality discrimination in national representative teams can be properly safeguarded in

\footnotetext{
${ }^{76}$ Weatherill, "Anti-doping revisited - the demise of the rule of "purely sporting interest?" in Weatherill European Union Sports Law: Collected Papers (T.M.C. Asser Press 2008), p 345.

${ }^{77}$ Para 2.2.1.4 and para 2.4 of the Commission Staff Working Document, The EU and Sport: Background and Context, Accompanying Document to the White Paper on Sport, COM (2007) 391 final.

${ }^{78}$ Ibid. para 2.2.1.4.
} 
the objective justification/Meca-Medina frameworks. Proportionality limb in the analysis is allencompassing tool that can balance legitimate public interest objectives against economic freedoms, while taking account of the specific characteristics of sport and its social and educational function within the meaning of Article 165(1) TFEU and paragraph 40 of Bernard on the one hand, and the free market requirements on the other.

\subsection{Inherent rules as objectively justified rules}

The inherent rule framework and objective justification framework overlap, and what constitutes inherent as opposed to objectively justified rule is a matter of rather futile distinction exclusive to internal market. Namely, the rules are analysed under two formally distinct analytical structures that will in either case produce identical outcomes in all factual situations when inherent rules are tested under objective justification framework. It is therefore submitted that rather than assisting the discourse of the law in any substantive terms, the nuances are strictly confined to form and as such they should not be maintained. The notion of inherent rule should be discarded.

The sole obstacle to unifying the inherent rule and objective justification framework in internal market lies in the treatment of sporting rules that affect market access and discriminatory rules on the one hand, and non-discriminatory sporting rules that affect the exercise of economic activity on the other. The Court in Deliège considered that selection rules which limited the number of participants in the high-level international competitions, and which did not involve national teams competing against each other, could not in themselves constitute restrictions on the freedom to provide services under Article 56 TFEU because "such a limitation is inherent in the conduct of an international high-level sports event, which necessarily involves certain selection rules or criteria being adopted". ${ }^{79}$ What exactly will constitute such inherent rule as opposed to a non-discriminatory rule that affect exercise of economic activity that is not inherent, is a question left opened. Would transfer windows in Lehtonen be considered inherent, had they not been discriminatory? Presumably, they would still be assessed under objective justification framework as they relate to the "essential purpose of a professional player's activity". But arguably, so do rules that prevent athletes from participating in Olympic Games like in Deliège. It could be thought that selection criteria for judokas that are formally classified as amateurs, in fact produces more profound impact on athletes, than a rule on transfer windows which is easy to comply with and is not overly restrictive.

Any other similar attempt to separate inherent rules and objectively justified rules in concrete terms will be unhelpful in practice and therefore unconvincing. Instead, it should simply be acknowledged that the inherent rules in fact go through the same analytical points as objectively justified rules, and that the two formally distinct analytical frameworks will always produce the same outcome. Thus, under the three-step objective justification test the Deliège selection criteria that enables national associations to send their best athletes to participate in high-level sports event would be considered restrictive on non-selected athletes, but objectively justified by the need for proper organisation of sport. It would also fulfil proportionality test because it was based on objective criteria and necessary (i.e., it was the least restrictive measure to attain the goals of the said justification). Parrish and Miettinen were of the opinion that "[a]lthough

\footnotetext{
${ }^{79}$ Joined Cases C-51/96 and C-191/97 Deliège, para 64.
} 
inherent rules do not constitute restrictions within the meaning of free movement law, the process of analysis involves an examination of proportionality of the rule and the relationship between fundamental rights and the rule purported to be inherent." 80

In competition law under Meca-Medina framework, the distinction does not exist: rules that affect market access and discriminatory rules, as well as non-discriminatory sporting rules that affect the exercise of economic activity, are subject to the same assessment criteria. Therefore, the final element in constructing the uniform framework is the convergence between internal market objective justification framework and Meca-Medina test in competition law. The instruction from Annex I of the Commission Staff Working Document is that, had the transfer periods in Lehtonen been proportionate, they would have been objectively justified not only under free movement law, but also under Meca-Medina test under Articles 101(1) and 102 TFEU. ${ }^{81}$ Advocate General Albert in Lehtonen similarly concluded that transfer periods are compatible with Article 101 TFEU to the extent that they may be reconciled with freedom of movement for workers. ${ }^{82}$ Significantly, this position by the Commission and the Advocate General is also an implicit reference to convergence between internal market and competition provisions in their application to regulatory rules in sport.

Both in law and in fact, objectively justified sporting rules under internal market law inevitably satisfy the Meca-Medina test under competition law and vice-versa, as they contain the same analytical points. ${ }^{83}$ On the other hand, whereas inherent rules under internal market will always satisfy the Meca-Medina test under competition law, the reverse will not always be true: discriminatory rules and rules affecting market access cannot satisfy the inherent rules test in internal market, and objective justification framework will apply only to produce the same result as under Meca-Medina test. Creating these structural obstacles to unifying the tests for regulatory rules in sport across the TFEU economic provisions, does not make much sense in terms of practical benefits or substance, and it is another reason why inherent rule test in internal market should be discarded. In Communication on Developing European Dimension in Sport the EU Commission more generally explained that in order to assess the compatibility of sporting rules with any EU law, it considers the legitimacy of the objectives pursued by the rules, whether any restrictive effects of those rules are inherent in the pursuit of the objectives and whether they are proportionate to them. ${ }^{84}$ First, every inherent rule does in fact pursue a legitimate aim and must be proportionate. In the Commission practice and the case law of the Court, including the opinions of the Advocate Generals, "inherent" is a synonym for "indispensable", "necessary", or "essential". Inherency can also be seen as one part of a full proportionality test, which includes an assessment of suitability (a measure is suitable, if it is capable of achieving the goal both legally and factually), inherency or necessity (a measure is inherent/necessary if, without taking these measures, the legitimate objective cannot be achieved), and proportionality (a measure is proportionate if does not go beyond what is necessary, and there are no less restrictive rules that are capable of achieving the same objective). This proportionality test is applied to sporting cases in accordance with the standard set out in paragraph 40 of Bernard that refers to Art 165(1) TFEU. The broad and flexible

\footnotetext{
${ }^{80}$ Parrish and Miettinen, op. cit. supra note xxx, p 101.

${ }^{81}$ European Commission, Commission Staff Working Document, Annex I, para 2.2.1.6.

${ }^{82}$ At para 108.

${ }^{83}$ Pijetlovic, op. cit. supra note $\mathrm{xxx}$, pp 228-233.

${ }^{84}$ Commission Communication on Developing European Dimension in Sport (2011), para 4.2.
} 
assessment criteria contained therein are capable of nourishing any special characteristic of sport in application of TFEU economic provisions. It is therefore a simple but powerful tool that can ensure the optimal application of EU law which perfectly balances economic and sporting considerations.

\subsection{Convergence and burden of proof}

Elsewhere, I have argued that there is a high degree of convergence between internal market and competition law in their application to regulatory rules in sport. ${ }^{85}$ Specifically, there is a full convergence between the free movement objective justification framework and the competition law Meca-Medina test, and the results are transplantable from one area to another without the need for separate analysis: the analytical points are the same in both tests. This is subject to two narrow exceptions that have already been discussed in Section 3.2 in the context of purely sporting rules. First, there is no convergence in regard to EU constitutional competence to act due to some very individual features of each set of norms, such as wholly internal situations under free movement provisions which do not preclude the application of competition law, or the requirement of appreciability under competition provisions which does not exist in internal market law. Similarly, there is no convergence as regards certain elements necessary to trigger the application of specific article, such as the concept of undertaking, agreement or decision, service, etc. Second, as per implications by the Court in paragraph 31 of Meca-Medina, in case of the unlikely existence of hard-core restrictions by regulatory rules under Article 101(1) TFEU convergence does not apply. This in turns means that the rules that satisfy the required criteria for the application of both sets of provisions and do not constitute hard-core restrictions under Article 101(1) TFEU (which is the most likely scenario in practice) will be subject to one uniform test only.

The only technical objection that can be raised to the proposed uniform test pertains to the burden of proof. Namely, under the first paragraph of Article 101 TFEU the burden is on the complainant, and in the third paragraph the burden is borne by the respondent. ${ }^{86}$ In free movement law, and under Article 102 TFEU, it is on the complainant to prove the existence of the restriction, while it is on respondent to prove that the restriction is objectively justified and proportionate. This sits uncomfortably with the Meca-Medina test that entirely falls within the scope of first paragraph of Article 101 TFEU, and as such demands the complainant to substantiate all the analytical points to the requisite standard of proof. Perhaps even more curiously, Meca-Medina test applies also in Article 102 TFEU. However, in Michelin II the General Court was unequivocal that the burden of proof for elements of the objective justification defence in Article 102 TFEU, a functional and substantive equivalent of Article 101(1) ancillary restraints, was on the respondent dominant undertaking. ${ }^{87}$ Also the Discussion Paper addressed this issue and said that

\footnotetext{
${ }^{85}$ Pijetlovic, op. cit. supra note $\mathrm{xxx}$.

${ }^{86}$ Article 2 of the Council Regulation 1/2003 of 16 December 2002 states that: "In any national or [Union] proceedings for the application of Articles [101] and [102] of the Treaty, the burden of proving an infringement of Article [101(1)] or of Article [102] of the Treaty shall rest on the party or the authority alleging the infringement. The undertaking or association of undertakings claiming the benefit of Article [101(3)] of the Treaty shall bear the burden of proving that the conditions of that paragraph are fulfilled."

${ }^{87}$ See Case T-203/01 Manufacture française des pneumatiques Michelin v Commission (Michelin II) [2003] ECR II-4071, paras 107-109.
} 
[e]xclusionary conduct may escape the prohibition of Article [102] in case the dominant undertaking can provide an objective justification for its behaviour or it can demonstrate that its conduct produces efficiencies which outweigh the negative effect on competition. The burden of proof for such an objective justification or efficiency defence will be on the dominant company. It should be for the company invoking the benefit of a defence against a finding of an infringement to demonstrate to the required legal standard of proof that the conditions for applying such defence are satisfied.

The burden of proof therefore shifts to the dominant undertaking when relying on the efficiency defence in Article 102 TFEU, equivalent to Article 101(3) TFEU, or the objective justification defence in Article 102 TFEU, equivalent to the Meca-Medina, Wouters and DLG style of exceptions under Article 101(1) TFEU. For the sake of convergence between the two competition law provisions, which is indispensable to maximise the rationality of applying the Meca-Medina test equally to both competition provisions, the structure of Article 101 TFEU should not be allowed to impede the utility of having the shared test. Doing otherwise could bring about bizarre outcomes in which a complainant is not successful in evidencing the disproportionality of the challenged rules under Article 101(1) TFEU, whereas the respondent is not successful in evidencing their proportionality under Article 102 TFEU. Also, if the complainant is the one that should prove all the elements of the Meca-Medina test, how could it be expected that the complainant should know what particular objective the rules were designed to protect by the governing body? For example, a complaint to the Commission pursuant to Article 7 of Regulation 1/2003 is drafted without any knowledge of the respondent's (subsequent) submission.

Prima facie, arguing for the reversed burden of proof in Article 101(1) TFEU seems to go against paragraph 55 of Meca-Medina and Article 2 of Regulation 1/2003. ${ }^{88}$ On a more careful examination, Recital 5 of that regulation explains that in the effective enforcement of EU competition law, which respects the "fundamental rights of defence", the burden of proof under Articles 101(1) and 102 TFEU should be on the authority alleging infringement, but then it goes on to say that the burden of proof "should be for the undertaking or association of undertakings invoking the benefit of a defence against a finding of an infringement to demonstrate to the required legal standard that the conditions for applying such defence are satisfied." This could conceivably be interpreted as allowing for the reversal of burden of proof. Outside of pure structural considerations it should not matter under which paragraph of Article 101 TFEU the defence takes place, the burden of proof should be on the party seeking to rely on the defence. Meca-Medina test in fact represents not a sward for complainant, but a shield for respondent, and as such constitutes critical part of the respondent's defence when their regulatory sporting rules have been challenged. Public interest objectives often cannot be translated into economic efficiencies so as to enable defence under Article 101(3) TFEU. This interpretation would, moreover, coincide and align the approach with that under the free movement provisions. For these reasons, in the light of the blurring divide between addressees of competition and internal market provisions and the pressing need to specify the parameters of convergence, it is submitted that the Court should re-examine paragraph 55 of Meca-Medina in which it implied

\footnotetext{
${ }^{88}$ Council Regulation (EC) No 1/2003 of 16 December 2002 OJ L 1, 04.01.2003, p 1-25. Art. 2 reads: "in any national or Community proceedings for the application of Articles 81 and 82 of the Treaty, the burden of proving an infringement of Article 81(1) or of Article 82 of the Treaty shall rest on the party or the authority alleging the infringement. The undertaking or association of undertakings claiming the benefit of Article 81(3) of the Treaty shall bear the burden of proving that the conditions of that paragraph are fulfilled."
} 
that the burden is on appellants to establish that rules were disproportionate. ${ }^{89}$ Examination of the regulatory and organisational sporting rules does not follow the orthodox analytical approach under Articles 101(1) and 102 TFEU, whereas Article 2 of the Regulation 1/2003 was drafted with that approach in mind. When dealing with private regulatory bodies such as sporting organisations where it is clear that both internal market and competition provisions apply to the same cases, this should not be allowed to create unnecessary additional confusion and futile differences.

The key function of the burden of proof is to identify the party that is required to establish evidence to the requisite standard of proof. At the same time, there is no standard of proof in EU competition law that is defined ex ante in terms of probabilities, and identifying it in the judgements appears to be rather an ex post construction by commentators. ${ }^{90}$ The Court's approach to standard of proof therefore seems to be largely impressionistic, as confirmed in paragraph 41 of Tetra Laval. ${ }^{91}$ Furthermore, according to Recital 5 of the Regulation 1/2003, national laws govern the matters of standard of proof when EU competition laws are applied by national courts and authorities. As such, it is a concept that fluctuates depending on the applicable national procedural law. In the EU, however, standard of proof is not a matter of procedure but of fact, and as such cannot be challenged on appeal.

Against this background, it becomes apparent that there are no particular advantages in preserving the current formal approach to burden of proof. It is a purely structural choice based on the rigid distinction between prohibition provision and exemption provision in Article 101 TFEU, which, for the sake of comparison, does not even exist in many legal systems. Choosing form over benefits such as efficiency, simplicity and convergence, serves neither any practical purpose nor competition law objectives any better than the reversed burden of proof. This outstanding aspect is therefore suitable for convergence in the application of the competition and internal market provisions to the regulatory rules in sport sector.

\section{Conclusion}

Nuances created by the Court in its structural approach to regulatory rules in sport might have been warranted when the EU sports law and policy was an emerging and novel discipline in search of itself. However, this legal area as it stands today can no longer justify the distinctions made in the formative phase. The general EU law parameters applicable to any industry are perfectly apt to accommodate all of the identified categories of regulatory rules in sport. Those parameters consist of a simple, all-encompassing uniform framework based on restriction justification - proportionality analysis, as accompanied by considerations enshrined in the concept of specificities of sports. Therefore, there exists no credible reason to maintain purely

\footnotetext{
${ }^{89}$ In paragraph 55 of C-519/04 Meca-Medina the Court held: "Since the appellants have, moreover, not pleaded that the penalties which were applicable and were imposed in the present case are excessive, it has not been established that the anti-doping rules at issue are disproportionate."

${ }^{90}$ A.-L. Sibony, "Le juge et le raisonnement économique en droit de la concurrence", L.G.D.J. (2008), at 746, cited in Gippini-Fournier, "The Elusive Standard of Proof in EU Competition Cases", 33 World Competition (2010), pp 187-207, at 4.

${ }^{91}$ Case C-12/03 P Commission v Tetra Laval BV [2005] ECR I-987. It was held that the evidentiary requirements placed on the Commission so not create a condition relating to the requisite standard of proof, but merely draw attention to essential function of evidence which is to establish convincingly the merits of an argument.
} 
sporting rules and inherent rules categories of sporting exception. The remaining two categories, sporting rules that produce no economic effect and objectively justified sporting rules, already fit into the ordinary EU law structure. The first one applies to any industry as economic effect is a constitutional requirement for Union action based on principles of conferral and subsidiarity enshrined in Article 5(1) TEU. The second one stems from the Court's internal market jurisprudence and contains all the elements needed to analyse any sporting rule that produces economic effect. It supplies a clear set of coherent rules that are designed to protect the Union's economic goals and at the same time nourish any specificities of sport in a balancing act of competing interests. In this context, proportionality principle as set out in Bernard and Article 165(1) TFEU is a powerful two-way filter: on the one hand, it will only allow economic considerations to prevail where the sporting rules are overly restrictive, or not restrictive enough, for the attainment of the legitimate goals. On the other hand, well-designed sporting rules that restrict economic freedoms will escape the condemnation under EU internal market and competition laws to the extent that they are suitable and necessary for their legitimate goals.

Convergence between the internal market and competition laws assists the single uniform framework and eliminates the need for identical duplicate analysis. It applies in all cases where the rules of sports regulatory bodies that are being challenged under both sets of provisions fulfil the required economic effect respectively. The operation of presumptions in competition law in cases of hard-core restrictions is the only exception to this statement.

A number of benefits flow from thus unified approach that heavily relies on Bernard/Article 165(1) TFEU standard of proportionality assessment. They include simplification of analytical structure, enhanced certainty for sports governing bodies, and sufficient flexibility for both national and Union enforcers. Therefore, it is to be hoped that the Court will recognise these advantages and adopt uniform algorithm in its evaluation of regulatory rules in sporting industry. 